manner and direction of the motions of the extremely lofty aircurrents in which the finely-divided material is suspended. A. S. Herschel

Collingwood, Hawkhurst, September 20

ON September 27 , being on the river about 6 p.m., I noticed the beautiful colour of the sky, which lasted for three-quarters of an hour after sunset. The day had been very cloudy, but not much rain had fallen, and about 4.30 p.m. the sky cleared and the sun shone out. My attention was drawn to the appearance of the sky about 6.15, after the sun had set. Great masses of red appeared in the west on a bacliground of gold and primrose ; above this the sky shaded from green into blue; the red colour extended upwards for about $40^{\circ}$, and appeared of various shades, deep red, magenta, and rose colour, the various small clonds which were floating about being pink. This red light gradually broadened out and died away, giving place to deep orange and gold, the latter colour lasting till 6.45 .

The water was as gorgeous as the sky above, the reflections of the trees being bright red and purple on a floor of gold. I may add that the red light from the sky was so strong that a rosy hue was thrown on some trees and everything around.

Hurley Mill, September 28

T. M. BROWNE

\section{September Stream of Krakatoa Smoke at Strong's Island}

AFTER long delay, owing to the wrecking at Strong's Island of the Morning Star, I feel very fortunate in coming into possession at last of a most important record of fact, which I hasten to publish, in the form of an extract from the journal of Miss Cathcart, the young lady missionary labouring at Strong's Island with Rev. Dr. and Mrs. Pease, and well known in Honolulu. It is as follows :-

"September 8. - Yesterday there was a very peculiar appearance of the sun. The sky was somewhat cloudy, but not so as to obscure the sun, which was of a silver blue colour, and not so bright but what we could look at it without any trouble. The shadow was the same as in an eclipse. There was no bright sunshine all day."

Although the journal contains no further record on the subject, nor any mention of the red glows which must have followed, it is so precise as to date and as to the phenomena observed as to be of the greatest value in continuing the history of the equatorial smoke-stream from Krakatoa beyond Honolulu and Fanning's Island, to which it had been continuously traced on its long route via the Seychelles, Cape Coast Castle, Trinidad, and Panama. It was observed by the barque Southard Hurlburt some 2000 miles east-south-east of Honolulu on September 3, at Fanning's Island on September 4, and at Honolulu in conspicuous brilliancy on the evening of the 5 th. Mr. Frank Atwater, landing at Maalaea, Maui, on the morning of the 5 th, observed a wonderful red glow, and marvelled much (having just arrived) if such were the sunrises in these islands. The same morning passengers on the Zealandia steaming southwards towards the line were awakened by blue sunlight streaming into their berths. Mr. F. L. Clarke has supplied a report, somewhat imperfect as to date, of an obscured and coppery sun seen at the Gilbert Islands on or about September 7. This would be September 6 in our reckoning, the Gilbert Islands being west of the meridian of $180^{\circ}$.

Now we have the very precise date given by Mis; Cathcart, of September 7 (6th) at Strong's Island, or just one day later than at Honolulu, and thirty-six hours later than the late afternoon coppery and lurid obscuration seen at Fanning's Island. Strong's Island is about 2320 miles nearly due west of Fanning's Island. This gives a rate of progress of the smoke-stream of sixty-four miles an hour. It seems proper to reckon time from Fanning's Island rather than from the Hawaiian Islands, as the latter were evidently north of the central course of the stream, and perceived its atmospheric effects haif a day later than the former, although nearly on the same meridian.

It is to be specially noted also that the phenomena were characterised by the peculiarities seen at Fanning's Island, as well as at Panama, rather than those seen at Honolulu. Here the obscuration of the sun was so slight as not to have been noticed during the day, nor was any change in its colour observed, except by Mr. and Mrs. H. M. Whitney, who saw its disk green at setting on the 5th. At Strong's Island, as well as at Fanning's Island, Panama, Trinidad, and eastward, the sun was heavily obscured, and its light changed to green at low altitudes, and blue when high up. This proves that the heavier thickness of the smoke-stream did not extend so far north as Honolulu, but was confined to a narrow belt near the equator. Fanning's Island is in lat. $2^{\circ} 40^{\prime} \mathrm{N}$., long. $159^{\circ} \mathrm{W}$. Strong's Island is in lat. $5^{\circ} \mathrm{N}$., long. $162^{\circ} 30^{\prime} \mathrm{E}$. The Zcalandiu was perhaps $5^{\circ} \mathrm{N}$. when the blue sun was observed. Honolulu is in lat. $22^{\circ} \mathbf{1} 7^{\prime}$ N., and received only the clouds fraying off from the edge of the smoke-belt as it swept by to the southward.

The sun's rays were so greatly obscurcd by the density of the smoke strata in the main belt that they seem there to have failed to produce the marvellous twilight effects which were so conspicuous in Honolulu. All along the line from Seychelles to Strong's Island, we hear of lurid appearances, green sun, blue light, great obscuration, sun easily observed with the naked eye, but hardly anywhere a word about twilight effects, or red glows; while at Honolulu, under the thinner side clouds of the stream, the colour effects in the twilight were amazing.

The topic is an endless one, and I will not prolong. Many ask what is the cause of frequent revivals of the red glows, such as the very fine one of last evening, August 19 . It seems merely to show an irregular distribution of the vast clouds of thin Krakatoa haze still lingering in the upper atmosphere. They drift about, giving us sometimes more, sometimes less, of their presence. It is also not unlikely that in varying hygrometric conditions the minute dust-particles become nuclei for ice crystals of varying size. This would greatly vary their reflecting power. This accords with some observations of Mr. C. J. Lyons, showing that the amount of red glow varies according to the prevalence of certain winds.

Hawaiian Government Survey, Honolulu, August 20

\section{Biology $v$. Botany}

ACCORDING to the regulations of the Cambridge $\mathrm{L}$ cal Examinations, 1883 , junior students can alone take botany, while senior students must take elementary biology instead. What has been the result? Taking the Regent's Park centre as a typical example, for it is a single school of several hundred girls, and sends up probably more than any other school in England, we find that from 1872 to 1882 , inclusive, 273 senior students entered, and 191, or 70 per cent. passed in botany. In 1883, however, none were sent up at all. If we ask, What is the object of teaching science in schools ? the answer is obviously for its educational value. Now this can only be acquired by practical study. Botany is eminently qualified for affording this use, whereas zoology is not. The lady principal of the school in question will not entertain the idea of teaching any branch of science if it cannot be taught practically, and very pertinently asks, "How can I get two to three hundred frogs, and make my girls dissect them? In the first place, the parents would not allow it." Consequently biology becomes a dead letter, and botany is discountenanced by the Syndicate for the elder girls.

On inquiring of a member of the Syndicate, I am informed that the gencral idea is that the juniors should study botany from this educational point of view, but seniors are of such an age that mere "object-lessons" are no longer necessary, but training in scientific thought is called for. Now, in the first place, it must be borne in mind that, from the pressure of other subjects, it is not generally, if ever, easy to teach science at all adequately in schools; and, secondly, the small amount of botany that can only possibly be taught, even to the elder pupils, is little more than practical descriptions, a certain acquaintance with the leading families of plants, and the general principles of physiology and histology. There is not the time to do more. As an examiner for the College of Preceptors for many years, and having to look over papers from schools, \&c., from all parts of England, I can testify to the fact that the standard of botanical teaching is decidedly low. Of course there are exceptions, but the majority, who get less than half marks, show little more than a smattering of the subject. Instead, therefore, of insisting on elder pupils advancing to biology, my own feeling is that it would be decidedly better to encourage seniors to continue the study of botany alone, but more thoroughly. The idea of calling such botany an "objectlesson" will sound somewhat ludicrous to my fellow teachers, who know what teaching practical botany thoroughly really means !

The remedy, therefore, seems obvious. Let the seniors as before pass in botany alone, but of a higher standard if you 